\title{
HUBUNGAN ORGANIZATIONAL COMMITMENT DAN TURNOVER INTENTION PADA PERAWAT
}

\author{
Triatno Yudho Prabowo \\ Program Studi Magister Psikologi, Universitas Tarumanagara Jakarta \\ Email:bowo16@gmail.com
}

\begin{abstract}
ABSTRAK
Tujuan penelitian ini adalah untuk mengetahui hubungan antara organizational commitment dengan turnover intention. Teori organizational commitment dikemukakan oleh Meyer dan Allen. Teori turnover intention dikemukakan oleh Tett dan Meyer. Organizational commitment merupakan usaha mendefinisikan dan melibatkan diri dalam organsasi dan tidak ada keinginan meninggalkannya. Turnover intention dapat dipahami sebagai niat secara sadar dan disengaja untuk meninggalkan organisasi. Penelitian ini melibatkan 64 responden. Penelitian ini menggunakan metode kuantitatif. Hasil penelitian menunjukan bahwa terdapat hubungan negatif antara dimensi organizational commitment (continuance commitment, normative commitment, affective commitment) dengan turnover intention meliputi : continuance commitment dengan turnover intention $(r=-0,362)$, normative commitment dengan turnover intention $(r=-0,714)$, dan affective commitment dengan turnover intention $(r=-$ $0,720)$.
\end{abstract}

Kata kunci: Organizational Commitment, Turnover Intention, Perawat

\section{PENDAHULUAN Latar Belakang}

Perawat memegang peranan penting dalam kegiatan operasional harian di rumah sakit (Okezone, 2017). Para dokter tidak dapat menjalankan tugasnya secara maksimal tanpa adanya peran perawat. Namun upaya untuk memenuhi kebutuhan akan tenaga perawat di rumah sakit bukannya tanpa kendala. Rumah sakit mengalami permasalahan turnover perawat yang tinggi. PricewaterhouseCoopers' Health Research Institute merilis hasil penelitian pada tahun 2007 bahwa rata-rata turnover perawat terdaftar di Amerika adalah sebesar 8,4\%. Kovner et al (2007) dalam penelitiannya menyebutkan bahwa sebanyak $13 \%$ perawat keluar dari pekerjaannya setelah masa kerja satu tahun.

Tingginya angka turnover karyawan dapat menimbulkan dampak negatif bagi perusahaan. Menurut Porter (dalam Surji 2013), bahwa turnover karyawan dapat membebani biaya perusahaan jika dikaitkan dengan berhentinya operasional kerja, rekrutmen, wawancara, orientasi, pelatihan, dan habisnya waktu. Porter menambahkan bahwa posisi entry level dapat menghabiskan biaya sekitar 50 sampai 100 persen dari upah karyawan. Maka menjadi penting bagi perusahaan untuk melakukan upaya agar tingkat turnover karyawan tidak tinggi. Selain itu menurut Curtis dan Wright (dalam Surji 2013), turnover dapat merusak layanan dan kualitas pelanggan sebagai ekspresi langsung pada perusahaan. Bothma dan Roodt (2013) menjelaskan kehilangan karyawan yang sangat terampil akan menimbulkan implikasi yang mengganggu bagi organisasi, seperti gangguan fungsi organisasi, pemberian layanan dan administrasi.

Salah satu upaya mencegah tingkat turnover karyawan yang tinggi adalah dengan meningkatkan organizational commitment. Hal ini karena tingginya turnover karyawan dapat menjadi indikasi adanya permasalahan terkait dengan organizational commitment. Meyer dan Allen (1991) menjelaskan bahwa organizational commitment merupakan keadaan psikologis yang mengikat seorang karyawan kepada organisasi, sehingga mengurangi terjadinya turnover. Ketiga dimensi organizational commitment dan turnover memiliki hubungan yang negatif (Meyer et all, 2002). Cohen (1993) dalam penelitannya mengemukakan bahwa hubungan commitment-turnover lebih 
kuat ketika pengukuran di antara keduanya berjangka waktu pendek. Lum et al (1998) menyampaikan bahwa organizational commitment merupakan faktor penentu yang paling penting dari turnover intention. Luthans (2011) menjelaskan bahwa kesimpulan dari penelitian terdahulu maupun yang baru menunjukkan adanya hubungan positif antara organizational commitment dengan hasil yang diinginkan seperti kinerja tinggi, tingkat turnover yang rendah dan tingkat ketidakhadiran yang rendah.

Penelitian ini dilakukan di Rumah Sakit Y. Rumah Sakit Y merupakan salah satu dari tujuh rumah sakit yang didirikan oleh Grup S. Rumah sakit pertama didirikan oleh grup S pada tahun 1981. Jumlah karyawan Rumah Sakit Y sebanyak 345 orang, 45\% atau 155 orang adalah perawat. Data turnover perawat Rumah Sakit Y pada tahun 2016 adalah sebanyak 13 orang dari total 153 perawat atau sebesar 8,5\%. Pada tahun 2017 turnover perawat di Rumah Sakit Y meningkat sebanyak 18 orang dari total 155 perawat atau sebesar $11,6 \%$.

Sejauh pengetahuan yang penulis miliki, di Indonesia belum banyak penelitian mengenai hubungan antara organizational commitment dan turnover intention yang khusus dikaitkan dengan profesi perawat. Sehingga penulis merasa tertarik untuk melakukan penelitian ini.

\section{Tinjauan Teoretis}

Organizational commitment merupakan usaha mendefinisikan dan melibatkan diri dalam organsasi dan tidak ada keinginan meninggalkannya (Robbins, 2006). Luthans (2011) menjelaskan sebagai sebuah sikap, organizational commitment sering didefinisikan sebagai (1) keinginan kuat untuk tetap sebagai anggota organisasi tertentu; (2) kesediaan untuk memberikan tingkat usaha yang tinggi atas nama organisasi, dan (3) keyakinan yang pasti serta penerimaan atas nilai dan tujuan organisasi. Meyer dan Allen (1997) merumuskan tiga dimensi organizational commitment, yaitu: Pertama, affective commitment yang berkaitan dengan hubungan emosional anggota terhadap organisasinya, identifikasi dengan organisasi, dan keterlibatan anggota dengan kegiatan di organisasi. Karyawan dengan affective commitment yang tinggi akan terus menjadi karyawan di perusahaan tempatnya bekerja karena memang memiliki keinginan untuk itu. Kedua, continuance commitment adalah terkait dengan kesadaran anggota organisasi akan mengalami kerugian jika meninggalkan organisasi. Karyawan dengan continuance commitment yang tinggi akan terus menjadi karyawan di perusahaan tempatnya bekerja karena mereka memiliki kebutuhan untuk itu. Ketiga, normative commitment adalah gambaran perasaan keterikatan untuk terus berada dalam organisasi. Karyawan dengan normative commitment yang tinggi akan terus menjadi karyawan di perusahaan tempatnya bekerja karena merasa dirinya memiliki keharusan untuk melakukan hal tersebut.

Turnover intention dapat dipahami sebagai niat secara sadar dan disengaja untuk meninggalkan organisasi. Turnover merupakan penghentian pekerjaan individu dengan perusahaan tertentu (Tett \& Meyer, 1993). Menurut Price (2001) turnover merupakan gerakan individu melintasi batas keanggotaan sebuah organisasi. Timbulnya turnover umumnya diawali dengan adanya turnover intention. Beberapa faktor yang mempengaruhi terjadinya intensi turnover menurut Jewell dan Siegall (1998) terdapat dua bagian yaitu, pertama terdapat variabel pribadi meliputi kepuasan kerja, usia, jenis kelamin, pendidikan, lamanya kerja, pelatihan kerja, profesionalisme, pengungkapan kebutuhan akan pertumbuhan pribadi, jarak geografis dari tempat kerja, dan keinginan yang diungkapkan untuk tinggal dengan organisasi itu. Kedua, variabel organisasional seperti sistem penghargaan, termasuk gaji, kesempatan promosi, dan sejauh mana kerja dalam suatu jabatan menjadi rutinitas. Seashore et al (dalam Wheeler et al, 2007) mengembangkan pengukuran turnover intention yang terdiri dari tiga dimensi. Pertama, thinking of quitting atau 
adanya pemikiran untuk keluar dari organisasi. Kedua, intention to quit atau intensi untuk keluar meninggalkan organisasi. Ketiga, intention of search another job atau intensi untuk mencari pekerjaan di tempat lain. Chen dan Francesco (2000) mengembangkan pengukuran turnover intention dalam tiga indikator. Indikator pertama adalah pemikiran untuk keluar dari pekerjaan saat ini. Indikator kedua yakni keinginan untuk mencari lowongan pekerjaan lainnya. Dan indikator ketiga yaitu adanya keinginan untuk meninggalkan organisasi dalam beberapa bulan mendatang.

Keterkaitan antara organizational commitment dengan berbagai referensi seperti turnover intention telah tersusun dengan baik. Literatur mengemukakan bahwa karyawan yang sangat berkomitmen adalah mereka yang paling tidak mungkin meninggalkan organisasi (Kuean et al, 2010). Karyawan dengan affective commitment yang tinggi terus bekerja dalam organisasi dikarenakan mereka ingin melakukannya atau want to (Meyer \& Allen, 1991). Karyawan dengan affective commitment yang tinggi memiliki kedekatan emosional yang erat terhadap organisasi. Hal ini menunjukkan bahwa karyawan tersebut memiliki motivasi dan keinginan untuk berkontribusi secara berarti terhadap organisasi dibandingkan karyawan dengan komitmen afektif yang rendah (Meyer \& Allen, 1997). Karyawan dengan continuance commitment yang tinggi tetap bekerja dalam organisasi karena mereka harus melakukannya atau need to (Meyer \& Allen, 1991). Continuance commitment tidak berhubungan dengan kecenderungan seorang anggota organisasi untuk mengembangkan suatu situasi yang tidak berhasil ataupun menerima suatu situasi apa adanya (Allen \& Meyer, 1997). Sedangkan karyawan dengan normative commitment yang tinggi merasa bahwa harus tetap tinggal dalam organisasi atau ougth to (Meyer \& Allen, 1991). Individu dengan normative commitment yang tinggi akan tetap bertahan dalam organisasi karena merasa adanya suatu kewajiban atau tugas. Lebih lanjut Meyer dan Allen (1991) menyatakan bahwa perasaan semacam itu akan memotivasi individu untuk bertingkahlaku secara baik dan melakukan tindakan yang tepat bagi organisasi.

\section{Rumusan Masalah}

Bagaimana hubungan organizational commitment terhadap turnover intention?

\section{METODE PENELITIAN}

Subyek penelitian ini berjumlah 64 orang dengan karakteristik meliputi : (1) Perawat baik lakilaki maupun perempuan; (2) Usia kerja minimal satu tahun; (3) Pendidikan minimal diploma. Jenis penelitian ini adalah penelitian kuantitatif dan noneksperimen dengan data yang diperoleh berupa angka-angka yang dianalisis secara statistik dan peneliti tidak memberikan perlakuan pada subyek penelitian. Penelitian ini terdiri dari dua variabel, yakni organizational commitment sebagai variabel bebas dan turnover intention sebagai variabel terikat. Teknik pengambilan sampel menggunakan purposive sampling, yakni pengambilan sampel yang berdasarkan atas suatu pertimbangan tertentu seperti sifat-sifat populasi ataupun ciri-ciri yang sudah diketahui sebelumnya (Notoadmodjo, 2010). Teknik tersebut dipilih karena peneliti mempunyai kriteria tersendiri dalam penentuan sampel. Pengambilan data dilakukan secara online dengan menggunakan kuesioner melalui google form. Alat ukur yang digunakan dalam penelitian ini meliputi : (1) Alat ukur Turnover Intention milik Universitas Tarumanagara yang terdiri dari 10 butir soal. Alat ukur ini merupakan adaptasi dari Turnover Intention Scale 6 atau TIS-6 yang dikembangkan oleh Roodt. TIS-6 memiliki reliabilitas Cronbcah's Alpha 0,80 (Bothma \& Roodt, 2013). Contoh butir soal dalam alat ukur ini adalah "Saya berpikir untuk tetap bekerja di perusahaan saya saat ini”. (2) Alat ukur Organizational Commitment milik Universitas Tarumanagara yang terdiri tiga dimensi meliputi : dimensi continuance commitment sebanyak 12 
butir soal, dimensi normative commitment sebanyak 14 butir soal, dimensi affective commitment dari 10 butir soal, sehingga total terdapat 36 butir soal. Alat ukur ini merupakan adaptasi dari Organizational Commitment Scale yang dikembangkan oleh Meyer dan Allen dan memiliki reliabilitas (koefisien alpha) untuk masing-masing dimensi affective commitment 0,87; continuance commitment 0,75 ; dan normative commitment 0,79 (Meyer \& Allen, 1991). Contoh butir dalam alat ukur ini adalah "Sebenarnya saya tidak terlalu membutuhkan pekerjaan di perusahaan ini". Masing-masing kuesioner menggunakan empat skala: 1 = sangat tidak setuju; 2 = tidak setuju; 3 = setuju; 4 = sangat setuju.

\section{HASIL DAN PEMBAHASAN}

Dari 64 responden yang mengisi kuesioner, maka didapatkan data sebanyak 23 orang adalah laki-laki dan 41 orang adalah perempuan. Berdasarkan tingkat pendidikan sebanyak 52\% responden berpendidikan Diploma, 2\% berpendidikan profesi, 39\% berpendidikan S1, dan 8\% berpendidikan S2. Berdasarkan status kepegawaian, sebanyak 36\% responden merupakan perawat kontrak dan $64 \%$ merupakan perawat tetap. Berdasarkan departemen atau bagian tempat responden bekerja didapatkan data sebagai berikut : 36\% dari Poliklinik, 34\% dari Rawat Inap, 8\% dari ICU (Intensive Care Unit), 8\% dari Unit Gawat Darurat (UGD), 6\% dari Kamar Operasi, 5\% dari Rawat Inap PICU, dan 3\% dari Rekam Medis. Berdasarkan usia kerja responden didapatkan data sebagai berikut : usia kerja 1-3 tahun sebanyak 41\%, usia kerja 4-6 tahun 30\%, usia kerja 7-9 sebanyak 8\%, dan usia kerja di atas 9 tahun sebesar $17 \%$.

Uji reliabilitas alat ukur turnover intention diperoleh hasil Cronbach's Alpha sebesar 0,854. Sedangkan untuk alat ukur organizational commitment diperoleh hasil sebagai berikut: (1) dimensi continuance commitment nilai Cronbach's Alpha sebesar 0,738 setelah membuang 4 butir soal sehingga sisa jumlah butir soal adalah sebanyak 8 butir; (2) dimensi normative commitment nilai Cronbach's Alpha sebesar 0,803; (3) dimensi affective commitment nilai Cronbach's Alpha sebesar 0,812.

Uji korelasi pearson two-tailed pada taraf kepercayaan 99\% ditemukan hasil sebagai berikut : (1) Terdapat hubungan negatif antara dimensi continuance commitment dengan turnover intention ( $r$ $=-0,362)$; (2) Terdapat hubungan negatif antara dimensi normative commitment dengan turnover intention ( $r=-0,714)$; (3) Terdapat hubungan negatif antara dimensi affective commitment dengan turnover intention $(r=-0,720)$. Lihat tabel 1 . 
Tabel 1. Hasil Uji Pearson Correlation

\begin{tabular}{|c|c|c|c|c|c|}
\hline & & $\begin{array}{l}\text { Continuance } \\
\text { Commitment }\end{array}$ & $\begin{array}{c}\text { Normative } \\
\text { Commitment }\end{array}$ & $\begin{array}{c}\text { Affective } \\
\text { Commitment }\end{array}$ & $\begin{array}{l}\text { Turnover } \\
\text { Intention }\end{array}$ \\
\hline \multirow{3}{*}{$\begin{array}{l}\text { Continuance } \\
\text { Commitment }\end{array}$} & Pearson Correlation & 1 &, $713^{* *}$ &, $672^{* *}$ &,$- 362^{* *}$ \\
\hline & Sig. (2-tailed) & &, 000 &, 000 &, 003 \\
\hline & $\mathrm{N}$ & 64 & 64 & 64 & 64 \\
\hline \multirow{3}{*}{$\begin{array}{l}\text { Normative } \\
\text { Commitment }\end{array}$} & Pearson Correlation &, $713^{* *}$ & 1 &, $794^{* *}$ &,$- 714^{* *}$ \\
\hline & Sig. (2-tailed) &, 000 & &, 000 &, 000 \\
\hline & $\mathrm{N}$ & 64 & 64 & 64 & 64 \\
\hline \multirow{3}{*}{$\begin{array}{l}\text { Affective } \\
\text { Commitment }\end{array}$} & Pearson Correlation &, $672^{* *}$ &, $794^{* *}$ & 1 &,$- 720^{* *}$ \\
\hline & Sig. (2-tailed) &, 000 &, 000 & &, 000 \\
\hline & $\mathrm{N}$ & 64 & 64 & 64 & 64 \\
\hline \multirow{3}{*}{$\begin{array}{l}\text { Turnover } \\
\text { Intention }\end{array}$} & Pearson Correlation &,$- 362^{* *}$ &,$- 714^{* *}$ &,$- 720^{* *}$ & 1 \\
\hline & Sig. (2-tailed) &, 003 &, 000 &, 000 & \\
\hline & $\mathrm{N}$ & 64 & 64 & 64 & 64 \\
\hline
\end{tabular}

\section{Pembahasan}

Penelitian ini ditujukan untuk mengetahui bagaimana hubungan organizational commitment terhadap turnover intention pada perawat di Rumah Sakit Y.

Hasil uji korelasi ditemukan bahwa ketiga dimensi organizational commitment yakni continuance commitment, normative commitment, dan affective commitment memiliki hubungan negatif dengan turnover intention. Hal ini berarti semakin tinggi tingkat organizational commitment perawat di Rumah Sakit Y dapat menyebabkan semakin rendahnya tingkat turnover intention atau sebaliknya.

Dimensi affective commitment memiliki hubungan negatif terbesar dengan turnover intention ( $r$ $=-0,720)$, diikuti dimensi normative commitment $(r=-0,714)$, kemudian dimensi continuance commitment ( $r=-0,362)$. Hal ini menunjukkan bahwa turnover intention di Rumah Sakit Y akan lebih disebabkan kedekatan emosional dan motivasi perawat untuk berkontribusi secara berarti terhadap perusahaan dibandingkan dengan perasaan memiliki kewajiban terhadap perusahaan dan persepsi perawat atas manfaat atau kerugian apabila meninggalkan perusahaan.

Hasil dari penelitian ini konsisten dengan hasil penelitian yang dilakukan oleh Meyer et. al (2002) yang menemukan bahwa ketiga dimensi organizational commitment dan turnover memiliki hubungan yang negatif. Dan hasil penelitian ini juga sejalan dengan pernyataan Luthans (2011) bahwa kesimpulan dari penelitian terdahulu maupun yang lebih baru menunjukkan dukungan terhadap hubungan positif antara organizational commitment dengan hasil yang diinginkan seperti tingkat kinerja yang tinggi, tingkat turnover yang rendah, dan tingkat absensi yang rendah. 


\section{KESIMPULAN DAN SARAN}

Berdasarkan hasil olah data dapat disimpulkan bahwa terdapat hubungan negatif antara organizational commitment dengan turnover intention. Hal ini menunjukan bahwa tingkat turnover intention akan rendah jika tingkat organizational commitment tinggi. Demikian pula sebaliknya tingkat turnover intention akan tinggi jika tingkat organizational commitment rendah.

\section{Saran}

Saran bagi perusahaan bahwa tingkat turnover intention perawat dapat diturunkan dengan meningkatkan organizational commitment terutama dimensi affective commitment perawat. Peningkatan affective commitment dapat dilakukan dengan cara membangun kedekatan emosional perawat terhadap perusahaan dan perasaan nyaman bagi perawat ketika berada di perusahaan.

Saran bagi penelitian selanjutnya agar pengambilan data dapat dilakukan secara langsung atau offline. Dengan pengambilan data secara langsung, peneliti sekaligus dapat melakukan wawancara dan observasi terhadap responden. Saat penelitian ini dilakukan peneliti mengalami kesulitan untuk mengumpulkan data karena saat penelitian ini dilaksanakan, Rumah Sakit Y sedang melakukan proses akreditasi sehingga seluruh karyawan tidak diperbolehkan melakukan hal-hal yang akan menyita waktu dan fokus dari proses akreditasi tersebut. Terkait dengan kondisi tersebut, pengambilan data penelitian ini dilakukan secara online. Selain itu perlu dilakukan penelitian lanjutan dengan jumlah responden yang lebih banyak dengan mengambil cakupan yang lebih luas seperti lingkup kabupaten/ kota atau propinsi.

\section{Ucapan Terima Kasih (Acknowledgement)}

Peneliti menyampaikan rasa terima kasih kepada Dr. Zamralita, MM, Psikolog, yang telah memberikan bimbingan dalam pelaksanaan penelitian ini. Ucapakan terima kasih juga disampaikan kepada Dr. P. Tommy Suyasa, Psikolog, atas bantuan terkait alat ukur yang digunakan dalam penelitian ini.

\section{REFERENSI}

Bothma, C. F. C., \& Roodt, G. (2013). The validation of the turnover intention scale. SA Journal of Human Resource Management.

Chen, L.Y., \& Francesco, A.M. (2000). Employee demography, organizational commitment, and turnover intentions in china: Do cultural differencesmatter? Human Relations, 53(6), pp. 869-887.

Cohen, A. (1993). Organizational commitment and turnover: A meta-analysis. Academy of Management Journal, 36 (5), pp. 1140-1157.

Jewell, L. N. \& Siegall, M. (1998). Psikologi industri atau organisasi modern. Terjemahan. Arcan, Jakarta.

Kuean, W. L., Kaur, S., Wong, E. S. K. (2010). The relationship between organizational commitment and intention to quit: The malaysian companies perspectives. Journal of Applied Sciences, 10 (19), pp. 2251-2260.

Lum, L., Kervin, J., Clark, K., Reid, F., \& Sirola, W. (1998). Explaining nursing turnover intent: Job satisfaction, pay satisfaction, or organizational commitment?. Journal of Organizational Behavior, 19, pp. 305-320 
Luthans, Fred. (2011). Organizational behaviour (12th Ed.). New York, NY: McGraw Hill.

Meyer, J. P., \& Allen, N. J. (1991). A three-component conceptualization of organizational commitment. Human Resources Management Review, 1 (1), pp. 61-69.

Meyer, J. P., Allen, N. J. (1997). Commitment in the workplace: Theory, research, and application. Thousand Oaks, CA: Sage Publications.

Meyer, J. P., Stanley, D. J., Herscovitch, L., \& Topolnytsky, L. (2002). Affective, continuance, and normative commitment to the organization: A meta-analysis of antecedents, correlates, and consequences. Journal of Vocational Behavior, 61, 20-52

Karnia, D. (2017 Mei 13). Peringati hari perawat sedunia, perawat punya peranan penting di rumah sakit. Okezone Life Style. Diambil pada 20 Oktober 2017. https://lifestyle.okezone.com/read/2017/05/13/481/1690184/peringati-hari-perawatsedunia-perawat-punya-peranan-penting-di-rumah-sakit

Notoatmodjo, S. (2010). Metodologi penelitian kesehatan. Jakarta: Rineka Cipta.

Robbins, S.P. (2006). Perilaku organisasi: Edisi Indonesia. Jakarta: PT Indeks Kelompok Gramedia.

Surji, Kemal M. (2013). The negative effect and consequences of employee turnover and

retention on the organization and its staff. European Journal of Business and Management, 55 (25).

Tett, R. P., \& Meyer, J. P. (1993). Job satisfaction, organizational commitment, turnover intentions, and turnover: Path and analyses based on meta analytic findings. Personnel Psychology, 46. 